Abstract 102 Table 2 Comparision of the levels of reduced glutathione and lipid peroxidation in Kidney, liver, lung and spleen at 0 month, 6 month pristane treatment and after resveratrol treatment. Values are expressed as Mean \pm SEM.

\begin{tabular}{|c|c|c|c|c|c|}
\hline & & Kidney & Liver & Lung & Spleen \\
\hline \multirow{3}{*}{$\begin{array}{l}\text { Reduced } \\
\text { Glutathione } \\
\text { (umolesing } \\
\text { protein) }\end{array}$} & 0 month & $4.53 \pm 0.37$ & $5.71 \pm 0.46$ & $9.67 \pm 1.35$ & $8.83 \pm 2.10$ \\
\hline & 6 month & $2.23 \pm 0.37$ & $2.03 \pm 0.86$ & $3.21 \pm 0.99$ & $4.91 \pm 0.91$ \\
\hline & Resveratrol & $5.13 \pm 0.57$ & $5.45 \pm 0.21$ & $5.59 \pm 0.1$ & $9.88 \pm 0.46$ \\
\hline \multirow{3}{*}{$\begin{array}{l}\text { Lipid Peroxidation } \\
\text { (umoles MDAmg } \\
\text { protein) }\end{array}$} & 0 month & $1.35 \pm 0.17$ & $2.34 \pm 0.5$ & $1.58 \pm 0.52$ & $1.58 \pm 0.27$ \\
\hline & 6 month & $7.56 \pm 0.78$ & $10.62 \pm 1.08$ & $5.01 \pm 0.53$ & $6.27 \pm 0.48$ \\
\hline & Resveratrol & $2.78 \pm 0.16$ & $4.22 \pm 0.53$ & $4.29 \pm 0.84$ & $3.74 \pm 0.69$ \\
\hline
\end{tabular}

Methods Fifty-eight patients were enrolled at initiation of belimumab and followed longitudinally for up to 53 months. Surveillance outcomes included the SLE Disease Activity Index 2000 (SLEDAI-2K), $100 \mathrm{~mm}$ Visual Analogue Scales for Physician's Global Assessment (PGA), fatigue, pain and general health, and the Systemic Lupus International Collaborating Clinics/American College of Rheumatology Damage Index (SDI). Assessment of treatment response included the SLE responder index (SRI). B lymphocyte stimulator (BLyS) levels were determined using ELISA.

Results SLEDAI-2K (median baseline score: 8.0; IQR: 4.013.8), PGA and corticosteroid use decreased during therapy, and patients reported improvements on fatigue, pain, and general health $(p<0.0001$ for all). SDI scores remained stable $(p=0.08)$. Patients with baseline SDI scores $>1$ showed decreased probability and prolonged time to attain SRI response (HR: 0.449; 95\% CI: 0.208-0.967), as did current smokers compared with non-smokers (HR: 0.103; 95\% CI: $0.025-0.427)$. In contrast, baseline BLyS levels $\geq 1.2 \mathrm{ng} / \mathrm{mL}$ predicted increased probability and shorter time to attain SRI response (HR: 2.566; 95\% CI: 1.222-5.387).

Conclusions Disease activity and corticosteroid usage decreased, patient-reported outcomes improved, and no significant organ damage was accrued during follow-up. Smoking and organ damage predicted reduced treatment efficacy. These findings might contribute to a better selection of patients who are likely to benefit from belimumab.

\section{A MASS CYTOMETRY (CYTOF) APPROACH TO STUDY B CELL ALTERATIONS DURING BAFF BLOCKADE TREATMENT WITH BELIMUMAB IN SYSTEMIC LUPUS ERYTHEMATOSUS}

'I Parodis*, 'D Ramsköld, ${ }^{2} \mathrm{~L}$ Tadepally, ${ }^{2} Y$ Chen, ${ }^{1} \mathrm{~A}$ Zickert, ${ }^{2} \mathrm{~J}$ Mikes, ${ }^{1} \mathrm{~K}$ Amara, ${ }^{2} \mathrm{~A}$ Achour, ${ }^{2} \mathrm{P}$ Brodin, ${ }^{1}$ I Gunnarsson, ${ }^{1} \mathrm{~V}$ Malmström. ${ }^{1}$ Karolinska Institutet, Department of Medicine- Rheumatology Unit, Stockholm, Sweden; ${ }^{2}$ Karolinska Institutet, Department of Medicine Solna- Science for Life Laboratory, Stockholm, Sweden

\subsection{6/lupus-2017-000215.104}

Background and aims Belimumab is a monoclonal antibody that inhibits soluble B lymphocyte stimulator (BLyS, also known as BAFF), approved for the treatment of systemic lupus erythematosus (SLE). Here, we sought to identify B cell alterations during belimumab treatment.

Methods Twenty-three SLE patients treated with belimumab were enrolled. Peripheral blood mononuclear cells were collected and cryopreserved at treatment initiation and at regular follow-up visits for up to 3 years. The samples were simultaneously assayed using mass cytometry. Cell counts were adjusted for total lymphocyte counts.

Results CD20 ${ }^{+}$B cells decreased over time $(\mathrm{p}<0.0001)$. We observed a rapid reduction of naïve $\left(\mathrm{CD} 19^{+} \mathrm{CD} 20^{+} \mathrm{Ig}\right.$ $\left.\mathrm{D}^{+} \mathrm{IgM}^{+} \mathrm{CD} 27^{-}\right)$and age-associated $\mathrm{B}$ cells $\left(\mathrm{CD} 19^{+} \mathrm{CD} 20^{+} \mathrm{CD} 11 \mathrm{c}^{+} \mathrm{CD} 21^{-}\right)$already at the first follow-up visit (month 3 ), followed by a continuous decrease $(\mathrm{p}<0.0001$ for both subsets), while double-negative memory B cells 
$\left(\mathrm{CD} 19^{+} \mathrm{CD} 20^{+} \mathrm{IgD}^{-} \mathrm{CD} 27^{-}\right)$declined significantly first at month 6 $(\mathrm{p}=0.033)$ and pre-switching B cells $\left(\mathrm{CD} 19^{+} \mathrm{CD} 20^{+} \mathrm{IgD}{ }^{+} \mathrm{CD} 27^{+}\right)$ showed a trend towards a decrease $(\mathrm{p}=0.052)$. Plasma cells $\left(\mathrm{CD} 138^{+} \mathrm{CD} 38^{+} \mathrm{CD} 27^{+} \mathrm{CD} 19^{+} \mathrm{CD} 3 \mathrm{e}^{-\mathrm{CD}} 20^{-}\right)$and switched memory $\mathrm{B}$ cells $\left(\mathrm{CD} 19^{+} \mathrm{CD} 20^{+} \mathrm{CD} 27^{+} \mathrm{IgD}^{-}\right)$remained stable during the study period, as did $\mathrm{T}$ cells and monocytes $(\mathrm{p}>0.2)$. Despite continuously decreasing SLE Disease Activity Index, immunological changes correlated with clinical improvements only during early time points (month $0-3$ ). Interestingly, high baseline B cell counts were predictive of non-attaining Lupus Low Disease Activity State at month 24 (area under the ROC-curve: 0.95).

Conclusions B cell alterations betided in two distinct phases, a rapid early and a gradual late phase. Late clinical improvements might reflect preceding immunological changes, implying that early treatment evaluation and discontinuation might underestimate delayed improvements reflecting the late B cell changes.

\section{TOLL-LIKE RECEPTOR 7-, BUT NOT TOLL-LIKE RECEPTOR 9-, MEDIATED INTERFERON-A PRODUCTION FROM PLASMACYTOID DENDRITIC CELLS IN PATIENTS WITH SYSTEMIC LUPUS ERYTHEMATOSUS}

K Sakata*, S Nakayamada, Y Miyazaki, S Kubo, K Nakano, Y Tanaka. University of Occupational and Environmental Health, The First Department of Internal Medicine, Kitakyushu, Japan

\subsection{6/lupus-2017-000215.105}

Background and aims Aberrant and persistent production of type I interferon (IFN) is known to play a pivotal role in the pathogenesis of systemic lupus erythematosus (SLE), and plasmacytoid dendritic cells ( $\mathrm{pDCs}$ ) are the major source of type I IFN upon toll-like receptor 7 (TLR7) and TLR9 stimulation. However the respective impacts of TLR7 and TLR9 responses on type I IFN production in SLE has not been addressed.To investigate the precise function of pDCs in SLE patients, we shed light upon the differential regulation of TLR7/9 responses during type I IFN production from pDCs.

Methods PBMCs from SLE patients and healthy controls were analysed in the presence of a TLR7 agonist loxoribine and a TLR9 agonist CpG2216. The IFN- $\alpha$ production in Lin-HLADR+CD123+CD11c- pDCs was detected by flow cytometry.
Results We demonstrated that TLR7-mediated IFN- $\alpha$ production were up-regulated and were positively correlated with disease activity, conversely, TLR9-mediated IFN- $\alpha$ production were down-regulated in SLE. The differential regulation of TLR7/9 responses of pDCs was not dependent on expression levels of TLR7/9. Furthermore, in vitro experiments revealed that up-regulation of TLR7 response was caused by pre-treatment with type I IFNs, conversely, down-regulation of TLR9 response was caused by pre-treatment with type II IFN.

Conclusions This is the first report demonstrated the differential regulation of TLR7- and TLR9- mediated IFN- $\alpha$ production from pDCs in SLE, namely, caused by priming effects of type I and type II IFNs. Taken together, TLR7-, but not TLR9-, mediated IFN- $\alpha$ production contributes the pathogenesis of SLE, and TLR7 could be a potential therapeutic target for SLE.

\section{6 EFFECTS OF BELIMUMAB ON CORTICOSTEROID USE IN
A PIVOTAL PHASE III, RANDOMISED, PLACEBO
CONTROLLED STUDY IN SUBJECTS WITH SYSTEMIC
LUPUS ERYTHEMATOSUS IN NORTH EAST ASIA}

${ }^{1} \mathrm{Y}$ Tanaka*, ${ }^{2} \mathrm{D}$ Bass, ${ }^{2} \mathrm{M}$ Chu, ${ }^{3} \mathrm{~S}$ Egginton, ${ }^{3} \mathrm{~B} \mathrm{Ji},{ }^{4} \mathrm{~B}$ Pobiner, ${ }^{2} \mathrm{D}$ Roth, ${ }^{5} \mathrm{YW}$ Song, ${ }^{4} \mathrm{~A}$ Thompson, ${ }^{6} \mathrm{~F}$ Zhang. 'University of Occupational and Environmental Health, The First Department of Internal Medicine- School of Medicine, Kitakyushu, Japan; ${ }^{2}$ GSK, Collegeville, Pennsylvania, USA; ${ }^{3}$ GSK, Stockley Park, Uxbridge, UK; ${ }^{4}$ GSK, Raleigh Durham, North Carolina, USA; ${ }^{5}$ Seoul National University Hospital, Seoul, Seoul, Republic of Korea; ${ }^{6}$ Peking Union Medical College Hospital, Chinese Academy of Medical Sciences and Peking Union Medical College, Beijing, China

\subsection{6/lupus-2017-000215.106}

Background and aims Steroid reduction is an important treatment goal in systemic lupus erythematosus (SLE). The steroidsparing effects of belimumab were investigated in subjects in North East Asia.

Methods This multicentre, 52 week study (1 13 750/ NCT01345253) randomised (2:1) subjects ( $\geq 18$ years) with SELENA-SLEDAI ${ }^{38}$ to intravenous belimumab $10 \mathrm{mg} / \mathrm{kg}$ or placebo every 28 days, plus standard SLE therapy. Multiple measures of steroid use (prednisone equivalent) were made, including a secondary endpoint of reduction in dose over 52 weeks among subjects receiving $>7.5 \mathrm{mg} /$ day at baseline

Abstract 106 Table 1 Prednisone dose over 52 weeks

\begin{tabular}{|c|c|c|}
\hline All subjects $(\mathrm{N}=677)$ & Placebo $(n=226)$ & Belimumab $10 \mathrm{mg} / \mathrm{kg}(\mathrm{n}=451)$ \\
\hline $\begin{array}{l}\text { Baseline prednisone dose (all subjects), } \\
\text { mean (SD), mg/day }\end{array}$ & $\begin{array}{l}17.2 \\
(10.82)\end{array}$ & $\begin{array}{l}16.0 \\
(10.66)\end{array}$ \\
\hline $\begin{array}{l}\text { Cumulative prednisone dose over } 52 \text { weeks } \\
\text { (all subjects), median }\left(25^{\circ}, 75^{\infty} \text { percentile), mg* }\right.\end{array}$ & $\begin{array}{c}4758.1 \\
(3597.5,6695.0)\end{array}$ & $\begin{array}{c}4190.0 \\
(3090.0,5475.0)\end{array}$ \\
\hline p-value ${ }^{b}$ & \multicolumn{2}{|c|}{0.0005} \\
\hline $\begin{array}{l}\text { Number of subjects with baseline prednisone dose } \\
>7.5 \mathrm{mg} / \mathrm{day}, \mathrm{n}(\%)\end{array}$ & $\begin{array}{c}184 \\
(81.4)\end{array}$ & $\begin{array}{c}352 \\
(78.0)\end{array}$ \\
\hline $\begin{array}{l}\text { Number of days that prednisone was reduced to } \\
\leq 7.5 \mathrm{mg} / \text { day and/or by } 50 \% \text { from baseline over } \\
52 \text { weeks, median (25 } 25^{\star}, 75^{\star} \text { percentile) }\end{array}$ & $\begin{array}{c}0 \\
(0,172.0)\end{array}$ & $\begin{array}{c}0 \\
(0,213.5)\end{array}$ \\
\hline p-value ${ }^{b}$ & \multicolumn{2}{|c|}{0.0288} \\
\hline $\begin{array}{l}\text { Prednisone reduction by } \geq 25 \% \text { from baseline to } \\
\leq 7.5 \mathrm{mg} / \text { day during Weeks } 40-52, \mathrm{n}(\%)^{c}\end{array}$ & $\begin{array}{c}20 \\
(10.9)\end{array}$ & $\begin{array}{c}55 \\
(15.6)\end{array}$ \\
\hline$p$-value d & \multicolumn{2}{|c|}{0.0721} \\
\hline
\end{tabular}

-Daily dose imputed after dropout/treatment failure; "rank ANCOVA

among subjects with prednisone dose $>7.5 \mathrm{mg} /$ day at baseline; 'logistic regression;

ANCOVA, analysis of covariance; SD, standard deviation. 